\title{
Well-being and Mobility of Female-Heads of Households in a fishing village in South India
}

\author{
Fazeeha Azmia ${ }^{a *}$, Ragnhild Lund ${ }^{\mathrm{b}}$ Nitya Rao $^{\mathrm{c}}$ and R.Manimohan ${ }^{\mathrm{d}}$ \\ ${ }^{a}$ Department of Geography, University of Peradeniya, Peradeniya, Sri Lanka; ${ }^{b}$ \\ Department of Geography, Norwegian University of Science and Technology,
}

Trondheim, Norway; ${ }^{c}$ School of International Development, University of East Anglia,

Norwich, United Kingdom; ' Department of Economics and Rural Development,

Alagappa University, Karaikudi, India

* Department of Geography, University of Peradeniya, Peradeniya, Sri Lanka,

\section{fazeehaazmi@gmail.com}

Fazeeha Azmi is a senior lecturer attached to the Department of Geography, University of Peradeniya, Peradeniya, Sri Lanka. Her research interests include post war youth, poverty and livelihood changes, women and migration, internal displacement and post war development in Sri Lanka. She has published journal articles and book chapters on gender, migration, youth and forced displacement in Sri Lanka.

Ragnhild Lund is professor of Geography/Development Studies at the Norwegian University of Science and Technology, NTNU, since 1994. Her research interests are theories of development and geography, gender and development, development induced displacement, post-crisis recovery, transnational feminism and women's activism. She has extensively published scientific articles on gender, youth, activism, forced migration, mobility, livelihoods, orphan hood/HIV/AIDS, and post-war recovery.

Nitya Rao is Professor, Gender and Development at the University of East Anglia, Norwich, United Kingdom. She has been a researcher, teacher and field-level practitioner for over thirty years. Her research interests include a gender analysis of agrarian relations, livelihoods and migration, educational choices and social mobility, intra-household relations and women's empowerment. 
R. Manimohan is working as Postdoctoral researcher at the Department of Economics and Rural Development, Alagappa University, Karaikudi, India. His research interests include the political economy of natural resource management and policy, particularly focusing on land, water and fisheries. 


\section{Well-being and Mobility of Female-Heads of Households in a fishing village in South India}

This paper focuses on how Female Heads of Households (FHHs) in a village in Cuddalore District, in the state of Tamil Nadu, India, have tried to achieve their various well-being targets and overcome their vulnerabilities through engaging in fish trading and auctioning that in turn involves moving within and outside their village. The study is based on a three-week fieldwork undertaken in April and May 2017, including multiple methods, such as observations, village walks, informal discussions, focus group discussions, and in-depth interviews. We address how FHHs' well-being intersects with old vulnerabilities that are an inherent part of their fishing culture (caste, class and gender) and new vulnerabilities created due to precarities related to mechanized fishing, modernization and post-tsunami development. We found that the complex situation of vulnerability and precarity in the fishing sector have affected the material, relational, and subjective wellbeing of FHHs differently, benefitting some female auctioneers but not the majority of fish vendors. In particular, the mobility of younger FHHs was restricted due to familial and social expectations.

Keywords: Female heads of households (FHHs), fish vendors, well-being, mobility, vulnerability

\section{Introduction}

The Indian fisheries sector has gone through rapid changes since the mid-1950s due to modernization, mechanization and commercialization, resulting in both overfishing and growing social inequalities (Bavinck and Johnson 2008; Salagrama 2006). Replacement of traditional fishing practices with modern ones, dependent on capital-intensive technologies, continue to challenge the livelihoods of small-scale fishers. These changes 
have further accelerated and intensified after the 2004 tsunami through the post-tsunami reconstruction programmes. Extensive distribution of boats and nets has resulted in growing competition and consequently increasing capitalization. This has contributed to increasing polarization between the rich and poor, sometimes strengthening existing inequalities in the local society.

The above processes are not gender neutral. They impact differently on men and women in terms of socio-economic position and marital status, with FHHs facing perhaps the worst impacts. The Indian fisheries sector, including coastal, inland, and aquaculture fisheries, employs over 14 million people directly, and many more indirectly. Women constitute more than 66 per cent of the total workforce in the postharvest fisheries (Department of Animal Husbandry Dairying \&Fisheries 2017), yet their well-being aspirations are continuously challenged due to changes taking place within and outside the sector. Although women make important contributions to fisheries and household survival, both in production and market relations, as fish vendors and auctioneers, their roles are undervalued and marginalized (Hapke 2001). Further, women in the fisheries sector are not a homogenous group, rather embedded in relations of class, caste and gender, constantly being renegotiated and reworked in the context of modernization, economic transformation, ecological crisis, local political power structures and the social constructions of femininity and masculinity (Ram 1991).

Other studies on the impacts of mechanization and motorization on fisheries in South India reveal the negative effects of such processes on small-scale fishers (Salagrama 2006; Vivekanandan and Kassim 2011; Salim et al. 2013; McGregor, Salagrama, and Bahadur 2016). Hapke and Ayyankeril (2018) list the socio economic outcomes of state led fisheries development programmes including the geographical shift in fish harvesting, sectoral split between and within fishing communities in the 
areas of access to capital and harbours, increase in the volume of long distance sources in local markets, overcapitalization, over-exploitation and ecological crisis, new geography of fish markets resulting from larger and long distance boats, increase in modern fish processing industries due to ice and refrigeration technologies, and technological innovation in fishing nets. This alters the gendered division of labour within fishing communities, albeit in different ways. Hapke and Ayyankeril (2018) document how in one of their study villages, women's role in fish marketing has increased, while in two other villages, with men moving out of fisheries and migrating to the Gulf countries, women have become housewives. Further, access to and availability of different types of assets, especially boats and nets, impacts the opportunities available to poor fishing households in general.

This paper focuses on FHHs involved in fish vending and auctioning. There are many reasons and ways for women to assume the headship of a household resulting in inconsistencies and complexities in defining who the female heads of households are (Chant 2004; Ruwanpura and Humphries 2004; Lund and Azmi in press). The respondent FHHs in our study are either the sole or the main economic contributor to their household, as they are widowed, divorced, separated or unmarried. First, we argue that the well-being aspirations of FHHs involved in fish vending and auctioneering are intertwined with contextual vulnerabilities created by the intersections of caste, gender and class. Second, we argue, that the recent precarity produced by mechanized fishing, coastal erosion, the 2004 tsunami, economic policies and technological changes in the fishing sector in India, have had divergent effects on women in the sector. While FHHs engaging as fish auctioneers have benefitted, expanding their networks into new and existing markets, fish vendors are largely unable to fulfil their well-being aspirations, or achieve social mobility. 
In the following section, we introduce the key concepts we have used in our analysis followed by a presentation of the study context in relation to caste, class and gender as well as influential structural factors, such as modernization, mechanized fishing and post-tsunami developments. Next, we present our methodology, methods and details of the study village before we discuss the main findings from our research on the wellbeing pursuits of FHHs. The subsequent section shows how their vulnerability is a differential force that works negatively for many and benefits only a few. The paper concludes by discussing how well-being pursuits must be seen in the context of vulnerability and precarity

\section{Conceptual clarifications}

As feminist geographers, we see the need to study how locality and social context are crucial factors in intersectional analysis (Crenshaw 1991; Valentine 2007; Peake 2010; Collins and Bilge 2016; Hopkins 2018). In this paper, we seek to reveal how a focus on the multiple facets of vulnerability confronting FHHs in fishing communities shape their well-being. Waite (2009) makes an analytical distinction between the concepts of vulnerability and precarity. While precarity refers to livelihoods characterized by uncertainty and insecurity that originate either from a generalized social malaise or from particular experiences derived from capitalist markets, in this case, post-tsunami development and the capitalization of fishing, thus focusing on the institutional and political contexts in which it occurs, vulnerability includes individual experiences of social marginalization, environmental insecurity, and inadequate physical and financial assets. Recent research on vulnerability in the Global South has distinguished between inherited vulnerability (low class, caste, and identity) and produced precarity. According to Rigg et al. (2016) extension of market relations under neoliberal reform can harm as well as assist certain groups or individuals and is temporal: 'Vulnerability 
is not merely accentuated or ameliorated over time, but it is re-worked because the causes, dynamics and texture of vulnerability also change' (Rigg et al. 2016, 65).

Mobility is a social and geographical phenomenon located in time and space (i.e. it is contextual,) as well as a gendered phenomenon (Hanson 2010). As a gendered phenomenon, mobility is 'embedded in, and interacting with, the household, family, community and larger society’ (Kusakabe et al. 2015). In this paper, we demonstrate how these women strategize and demonstrate agency by being mobile in their search for wellbeing and sustainable livelihoods in situations of vulnerability and precarity (Kusakabe et al. 2015). Mobility as a livelihood strategy is a difficult but necessary survival strategy for FHHs.

Since the late 1990s, the scholarly focus on the concept of well-being has resulted in its identification as a multidimensional and context-specific concept (McGregor and Sumner 2010; Britton and Coulthard 2013; Sumner and Mallett 2013; Weeratunge et al. 2014; White 2017). These scholars argue for a 'three dimensional' social well-being approach, which puts together material, relational, and subjective dimensions of well-being. The material dimension refers either to the resources people have or to the outcome of well-being. The relational dimension of well-being emphasizes the importance of socially constructed relationships for people's well-being, whereas the subjective dimension refers to how people feel about achieving their goals.

Britton and Coulthard (2013) recommend the use of the 'social well-being approach' in fisheries research as it may indirectly and ultimately benefit fisheries policy and governance. Although there is a growing literature on women in fisheries (Hapke 2001; Gopal et al. 2014), little research has targeted the well-being of women in fishing communities and more specifically FHHs of fish vendors and auctioneers who work hard to achieve their various well-being targets. In this paper, we use the three dimensions of 
well-being - material, relational, and subjective - as understood by the FHHs themselves hence our paper is not about identifying outcomes of well-being for FHHs but it is an attempt to illustrate how well-being is understood locally and among this particularly vulnerable group of women. Following the discussion above we need to distinguish between the varied structural dimensions which make these women vulnerable, and in some cases even making their livelihoods precarious.

\section{The Study Context}

\section{Caste, class and gender}

Caste, class and gender in fishing communities have complex interconnections and interactions that create different opportunities and social positions for men and women (Ram 1991). As such, fishing in India has a strong caste identity, and while fishing villages are generally characterized by a single caste, variations amongst them creates social stratification. In the Coromandel Coast of Tamil Nadu, where the study village is located, a majority of the fishing communities belong to the Pattinavar caste, a dominant fishing caste in the locality, known for their ocean fishing skills (Bharati 1999).

Within the context of Indian coastal fishing communities, caste plays a crucial organizing function, by controlling the division of labour, allocation and management of resources, and resolution of conflicts. Salagrama (2006) identifies caste as an important binding force as well as a barrier in fishing. While preventing the entry of outsiders to fishing, it also restricts caste members from finding other livelihoods. With the modernization in fisheries, class has emerged as an important social identity in fishing communities (Hapke 2018). Those who own mechanized boats and target export 
markets form one class, while small-scale fishers who mainly target local markets form another class.

Alongside caste and class, gender identities are differentiated and play an important role in shaping the household division of labour in fishing communities in South India. Hapke (2001) found in her South Indian study that fish trading is primarily undertaken by married women, widows and women whose husbands were disabled. Salagrama (2006) identified older women and widows as the most vulnerable groups in fishing communities, becoming progressively weaker in the face of the rapid changes taking place in the fishing sector. In our study too, women with economic responsibilities due to widowhood, separation, husband's physical inability to work, or being single and living alone, took to fish vending. The cultural expectations regarding widows and divorced women contributes to the context of vulnerability in which such women make their livelihoods. Chen (2010) points out how widows are considered inauspicious and believed to bring bad luck. Separated and divorced women too are generally stigmatized in Indian society and the study area was no exception. Socially marginalized due to their marital status, these women face challenges in accessing fish markets, loans or finding other types of employment. While half of them had males above 18 years in their families, they too did not have employment ( 7 families) or had only irregular employment (2 families), illustrating the economic vulnerability of FHHs.

\section{Modernization, mechanization and post-tsunami development}

A series of interventions have been undertaken by various Indian governments to modernize the fishing sector, improve fishers' income and tap the potential of foreign markets through large-scale, modern, capital and technology intensive programmes (Salagrama 2006). Between 1950-2010, the contribution made by the mechanized and motorized sector has increased in Tamil Nadu and Puducherry, while the non-motorized 
sector, on which the majority of small-scale fishers depend, has declined (Vivekanandan and Kasim 2011). This has led to a shift from small boats, landing in village beaches, to larger boats, taking their catch directly to harbours. The same trend can be seen in the study village, where previously fishing was done from small vessels called catamarans with various types of fishing gear, including beach seines and lift nets, in geographically demarcated fishing zones. However, since the 1960s, the Government of Tamil Nadu has promoted the use of mechanized boats, based in new harbour locations.

Due to modernization and mechanization the lives and livelihoods of the fishing community in fishing villages have changed. Fishers in a village with mechanized boats, have gradually shifted their fishing areas from near-shore to deep sea. This has increased the amount of fish caught and consequently the local fish markets became too small for business activities. The fish caught in the deep-sea targeted the market in the town and wholesale buyers. The situation affected the local female fish vendors, who depended on the village landing sites for fish. The depletion of fish resources along the shore due to mechanized fishing boats has also negatively affected small-scale fishers, increasing the gap between those with modern gear and those without. With small scale fishermen losing out, many women had to compensate for the loss of income through vending or other employment. Those women who could muster more resources and had the required social networks, started advancing money to boats in return for rights to auction the catch on a commission basis.

In 2004, when the tsunami hit the coastal areas of India, the small-scale fishing sector suffered the most in terms of loss of lives, and destruction of boats, fishing equipment and fishing infrastructure. The post-tsunami reconstruction transformed the fishing sector overnight, in terms of ownership of mechanized boats, fishing technology, fish landing sites and organization of labour. As a post-tsunami response, 
providing fishing boats to those who worked as fish labourers and fish traders created a surplus in fishing boats and increased the exploitation of fishing stocks, a trend that did not exist earlier. Jeeva et al. (2011) observed significant changes in boat ownership, investments, loans, types of vessels used, engine types, and number of people dependent on fishing, with clear differences in the villagers' pre- and post-tsunami socio-economic conditions.

\section{Mobility and well-being}

Mobility is an important strategy used by villagers in the study areas for improving well-being outcomes. However, existing social, economic and political structures have created different opportunities and constraints for mobility of differently positioned individuals, with impacts on their well-being. According to the villagers, mobility in the village, has for a long time, been motivated by their livelihood needs, which required moving from one place to the other for fishing and fish vending. However, the villagers reflected that during the last $10-15$ years, mobility in the village has been motivated by poverty, aspirations for studies, trainings and new types of non-fishery-based livelihoods both outside the village and outside the country. While young people involve in mobility for non-fishery-based livelihoods, training and education, many middle-aged villagers engage in mobility either to continue their fishery-based livelihoods or due to poverty. These changes have also altered the well-being aspirations of the villagers in general.

\section{Methodology}

This study is based on field research carried out in a fishing village in the district of Cuddalore, located in the South eastern Coromandel coast of Tamil Nadu state. 


\section{The village}

Cuddalore District (latitude $11^{\circ} 43^{\prime} \mathrm{N}$ and longitude $79^{\circ} 49^{\prime} \mathrm{E}$ ) with a coastal length of $57.5 \mathrm{~km}$, has 46 fishing villages (Assistant Director of Fisheries 2015). Out of a total 2024 households in the study village (name not presented to preserve anonymity), predominantly a Hindu village, the fishing households constitute 66 per cent (1335), with a population of 5368 in 2010 (Central Marine Fisheries Research Institute 2010).

The fishing community in the village belong to the Pattinavar caste, with two sub-castes - Chinna Pattinavar and Periya Pattinavar. The majority of the fish workers and fish vendors belong to the Chinna Pattinavar sub caste, while the small number of Periya Pattinavar are mainly owners of trawlers and large boats. The latter, however, controlled the Ur panchayat, the main governing institution in the village, responsible for resource allocation, management and conflict resolution, as well as organizing the annual temple festival. The FHHs mentioned that the Ur Panchayat had been nonfunctional during the last two years due to caste conflicts relating to ring seine operations in the village.

Post-tsunami, the composition of fish catch on the east coast of Tamil Nadu changed with an increase in mackerel and oil sardines. Communities further down the coast took to using ring seine nets, and after some initial protest, the Chinna Pattinavars decided to adopt this technology, seeing it as the only way to survive the growing competition. The Ur Panchayat, dominated by the Periya Pattinavar trawl owners tried to restrict the use of this gear, as it challenged their interests. There was an impasse while negotiations were ongoing. The FHHs were worried that this dispute between the two castes, by affecting community cohesion and local governance, had created a gap between the villagers and the state, as the Ur Panchayat had thus far functioned as a 
bridge between the two, leveraging state support for fulfilling community well-being needs. It had also regulated fishing operations, thereby ensuring the survival of FHHs.

Another important aspect that characterizes the village is the annual fishing ban that begins on the $15^{\text {th }}$ of April and ends on the $15^{\text {th }}$ of June. Implemented in Tamil Nadu coastal areas since 2001, it serves as a conservation measure to protect nearshore fishers from mechanized bottom trawling. During this fishing ban period, considered as the high breeding period, mechanized boats and trawlers are not allowed at sea, but small motorized and traditional fishing boats are allowed to fish. Fishers belonging to the fishermen's cooperative are entitled to receive a compensation ranging from 40006000 Indian rupees (44-66 GBP) during this period. The fishing ban season has different impacts on those involved in fishing, depending on the nature of their livelihood. Men lack regular work at this time, forcing women to take on the major economic responsibilities for the household. Yet, fish catch being low, FHHs who depend on vending, rely heavily on moneylenders to fulfil their well-being expectations, increasing their vulnerability in the process.

According to our respondents, the 2004 tsunami devastated the village and altered not only its physical structure, but also its socio-economic fabric. The village suffered not only loss of lives, but also loss of houses, bridges, roads, fish landing sites, boats, and fishing equipment. Additionally, changes occurred in the village due to posttsunami fisheries reconstruction. Fibre Reinforced Plastic (FRP) boats, equipped with outboard motors, replaced the traditional kattumarams. New fishing facilities were provided to the village by NGOs and the national government. Those who could invest in equipment, either from their own savings or through accessing loans, were able to purchase shares in ring seine boats, to catch small pelagic fish such as sardines and 
mackerel. Receiving catch shares along with wages made them better off compared with fish workers/labour.

Fish vendors and auctioneers play an important role in post-harvest fisheries. While fish auctioneers serve as a link between fishers and fish vendors, fish vendors link fishers and consumers. In our study area, two fish auctioneers worked in the village fish landing site, and one in the Old Town fish market. Fish vendors, either bought their fish from the village auctioneers, operating in the village fish landing site, or from the Old Town market. While some of the fish vendors did their business in the town, others, especially those who were old and feeble, very young, or were able to get a fish stall in the village fish market, sold their fish in the village. The fish vendors with a stall in the village fish market are relatively more politically powerful as compared to those selling their fish door to door in the village. Compared to fish vendors, we found that fish auctioneers were in a better economic and social position, having good business relationships with fishers. The fish auctioneer working in the Old Town fish market has invested in a boat, while the other two, working in the village, pay for fuel for boats and thereby manipulate the local fish market.

The majority of fishers in the village now sell their catch at the harbour to wholesale buyers. This move was driven by the post-tsunami construction of a Rubble Mounted Sea (RMS) wall to prevent coastal erosion. This seawall has however reduced the space for shore-based activities, limiting access to village fish landing sites, and thereby creating a precarious condition for women fish vendors, who could earlier easily access the beach-landing site. After some negotiation with government officers, a small space has been left open for docking small boats. The main fish auctioning place now in Cuddalore Old Town harbour is $10 \mathrm{~km}$ from the village. As public transport is not available during the early morning hours, women have to hire three-wheelers and 
share the costs. While FHHs who are able to travel outside the village to buy fish, can access a greater variety at lower prices, those unable to do so, buy their fish at higher prices in the village landing site, or then buy cheap fish from small-scale fishers for resale in the village. Post-tsunami reconstruction of fisheries has then created a new social fabric in the village, marginalizing FHHs, but also widening the gap between the rich and poor, paving the way for an intensification of class divisions.

\section{Research participants and methods}

This study is part of a larger project, which explores the movements and well-being of fishers in Cambodia, India, and Sri Lanka and how these movements are affected by changing state policies, increased market exposure and unstable environmental situations. Ethnographic information detailed why and how mobile livelihoods and gendered subjectivities differ within fishing communities, while surveys in each country provided information on the major patterns uncovered through the ethnographic data. The surveys of households in all three countries were drawing on an enumeratoradministered questionnaire and national databases, focusing on the significance of mobility and migration as a strategy to alleviate poverty.

Data and information on the socio-economic context of this study village were derived from an ethnographic study conducted in spring 2017 as part of this project. The initial phase of the fieldwork for this sub-study included various cross-sectional walks with the local research team to understand the socio-economic and cultural context of the village and gain insights about the distribution of different caste and class groups. Two of the authors, well versed in the local culture and language, were involved in data collection in the field, which provided the needed contextual background on the village and helped identify key participants. 
The village walks were conducted in the mornings and afternoons. In the morning, they covered fish landing sites where fish vendors met to buy fish, often from the auctioneers, and then went to sell the fish in the village and outside it. In the afternoon, the village walks provided a picture of how fish vendors and fish auctioneers engaged in household chores, stored the unsold fish, went to the Kovil (temple), or visited friends and relatives. Following the village walks, informal discussions were held with fish workers on the shore (three men, individual discussions), a boat owner (one man, individual discussion), fish vendors (four women in a group discussion), and a former Panchayat leader (individual discussion). With the exception of the former Panchayat leader and boat owner who belonged to the Periya Pattinavar caste, all other participants belonged to the Chinna Pattinavar caste. The discussions provided information on the socio-economic and institutional context of the village, and community members' views on their future, on current issues, and their expectations about the well-being of their community.

The informal discussions with villagers in one FGD helped identify the FHHs in the village, mainly widows, divorced women, and married women whose husbands were not contributing to the household economy due to illness or old age. Of these categories, widows constituted the highest number. Most of them lacked income earning partners and were responsible for many dependents. They were earners as well as responsible for the maintenance of the households. The identified FHHs provide a good example of a category worth paying attention to. The FHHs included in the study varied in marital status, age, number of dependents, age at marriage, caste, livelihood activities, level of education, length of time they had been the household head, and the employment status of male members in their households. All these factors placed them in different positions in their pursuit of well-being and their experience of vulnerability 
(Table 1).

[Table 1 near here]

The focus group discussion (FGD) was held to capture how the FHHs understood and conceptualized well-being, what the women needed in order to live well, the problems faced by FHHs, the impacts of natural disasters, post-tsunami development activities, and recent socio-economic changes that had taken place both within and outside their village. Although a second FGD was planned with non-fishing FHHs, and was arranged three times, only one or two women turned up at the allocated time and place, and eventually we had to abandon the FGD. However, we used this opportunity to secure interviews with two of these women later. The FGD included six women fish vendors, as attempts to include other villagers failed due to their unwillingness to reveal their opinions in an FGD dominated by fish vendors. Particularly, fish vendors who were not widows and fish auctioneers in the village did not participate in the FGD. They were socially better off than the widows and did not wish to participate in the FGD due also to the social stigma associated with widowed fish vendors.

The next stage in our research entailed individual in-depth interviews. The snowball method was used to identify potential research participants, with the help of the villagers and FGD participants. During the FGD, participants recommended other potential FHHs in the village who could be approached for interviews. In total we were able to conduct individual interviews with 18 FHHs. We used a semi-structured interview guide, which included questions relating to the basic socio-economic condition of the FHHs and their families, and their views on material, relational, and subjective well-being. Before starting the interviews, we made each research participant 
aware of the purpose of the research and assured them of data confidentiality. The interviews with the fish vendors (15) and auctioneers (3) were held mainly in the afternoon, after their business hours. The interviews lasted approximately $1-1.5$ hours and in some cases follow-up interviews were held at the fish market and at fish landing sites. The interview data were transcribed and translated into English for analysis.

\section{FHHs' Understanding of Well-being}

\section{Material Well-being}

With respect to material well-being, the FHHs placed strong emphasis on having a regular income, as this was important to meeting their various material needs. Four FHHs did not have a regular job that ensured regular income, 8 FHHs mentioned that at least one of their dependent family members worked in fishing, and only one FHH had a family member with a regular job, working in a shop. When regular jobs were not available in their community, FHHs obtained loans, engaged in other fishing-related activities such as preparing dry fish, or drew from their savings in order to make ends meet.

Savings were an important determinant of material well-being among the FHHs, as they helped to ensure that they had food during difficult times, such as the fishing ban season. Of the 18 FHHs with whom we held in-depth interviews, 6 mentioned that they had already started saving money for their future needs, which included weddings, funerals, medical expenditures and other unexpected needs. Since the FHHs did not have any knowledge about or access to formal saving institutions, they kept their savings in the form of cash at home. They also saved money through a rotating saving system (seettu) with their friends, relatives, fellow workers, or neighbours. Although 
this mode of saving is informal, for the FHHs and other women in the village, it provided some form of financial security, important for their well-being.

Another form of saving for FHHs was jewellery. Although widows did not wear gold jewellery, they considered owning it important for their material well-being. Five FHHs mentioned that they owned jewellery, which they could pawn or sell when they or their family members needed money. They also saved jewellery for their daughters' dowries, as is common practice in many Indian families. With rising capital needs in fishing, dowry payments too have been rising.

Housing was identified as an important material dimension of well-being by FHHs, the majority of whom (16 out of 18) lived in separate houses provided by housing schemes after the 2004 tsunami. Before the tsunami, most villagers had lived close to the beach in poor quality houses. Although almost all of the post-tsunami houses had water and electricity, with regular public water supply through standpipes, the FHHs mentioned that the quality of drinking water was not good. Some families arranged for water purifiers supplied by private companies, but the majority bought water from water supply trucks. The quality of water was highlighted as an important material dimension in well-being because it involved a financial cost. Many families could not afford to have a water purifier at home.

The interviews revealed that storage facilities for fish were a key indicator of material well-being, since such facilities were essential for the FHHs' livelihoods. Only four women had cold storage facilities for fish at home, and one used her neighbour's fridge, to save unsold fish. Others dried any fish they could not sell but expressed their concern over the lack of space for drying fish in their village. 


\section{Relational well-being}

In terms of relational well-being the FHHs emphasized the importance of intrahousehold relations. They prioritized considerate and well-behaved children, a good husband, and a peaceful and happy family life. They repeatedly highlighted the importance of having a good future for their children when expressing their views on well-being. Worried about the quality of educational facilities in the village, they were concerned about education and employment opportunities outside fishing for their children's well-being:

What I view as well-being is the well-being of my children. The educational facilities are not good in the village. We have to send them out to get good education. Even if they are educated, getting a job is another problem. I am not sure of the future of fishing in our village (Widow, aged 37 years, fish vendor).

While her reflection on well-being shows how the future of her children was important for her own well-being, it also shows her fears and hopes. The FHHs who had female children were very worried about their daughters' future, as they did not want their daughters to end up as fish vendors. They emphasized the importance of dowries to enable their daughters to marry well; in fact, this was a major source of indebtedness for many of them.

While having a male household head appeared critical for accessing state benefits, such as the fishing ban compensation, most of the widows and separated women mentioned that they did not have a good marriage, mainly due to their husband's alcoholism. For them, having a good husband went beyond economic contributions to the love, care, and respect they expected from their partners:

Having a good husband and a family life is most important in a woman's life. I did not get both (Widow, aged 46 years, fish vendor). 
Several FHHs had lost their husbands at a young age due to alcohol-related suicide, killing, or disease. Because of their husband's alcohol habit, they and their children were subject to physical harassment and had developed social and psychological problems. Even though these women were emotionally better off after the death of their husbands, they were worried about the social stigma and isolation confronted by widows and separated women. Most of the FHHs did not have their inlaws living with them, yet they were worried about in-laws' surveillance.

Relationships with neighbours were crucial for FHHs who were not involved in any income earning activities until their husbands died or until they were separated. One FHH who had recently taken on the role of household head said:

Until my husband's death, I did not do any job. We had one daughter and what my husband earned was enough for us. But after his death, I started to work as a fish vendor. I approached my neighbours for help. I went with them to buy fish in the village. I am not sure how I can continue this job as I am not well (Widow, aged 55 years, fish vendor).

This woman did not have any relatives in the village. She had only one daughter, who was divorced and living with her. Her husband's death had pushed her to become a fish vendor even though she had not worked earlier. For her, the relationship with her neighbours and fellow fish vendors was crucial to her ability to buy fish, and indeed wellbeing. These women interacted closely with each other. When they went to buy fish from the auctioneers on the beach, they pooled their money and shared the cost of one heap of fish, as none of them alone could afford to buy the whole heap. Similarly, they shared the transportation costs when they left the village to buy and sell fish, communicated with each other after work and spent their leisure time together. Such collective action shows the extent to which social relations were important for their 
well-being and how they used them as avenues though which to pursue their wellbeing goals.

Three of the interviewed FHHs were auctioneers. Although the precarious situation created by mechanization and commercialization of fisheries worked negatively for fish vending FHHs, the process worked positively for fish auctioneers, enabling them to invest and grow. FHHs who could not access wholesale fish traders depended on auctioneers for their fish. Considering the growing uncertainty in accessing fish, one of the auctioneers has invested in fishing boats to ensure regular access to the catch of these boats. What mattered to them was the larger well-being of their community:

I am happy and my family is doing well. The reason behind this is fish, the sea, fishermen, fish workers, fish vendors, buyers from outside, and customers. So, my wellbeing depends on the well-being of all these people and the kadal amma [Mother Sea] (Widow, aged 50 years, fish auctioneer).

The fish auctioneers had started their lives as fish vendors. They were well aware of the chain in the fish business and what could happen if it were broken. They agreed with the vendors on the difficulties in finding employment outside fishing that their children might face due to their caste, but also noted how class discrimination could affect their ability to obtain government jobs. They pointed out how the increasing numbers of mechanized boats after the 2004 tsunami, modern fishing nets, and political turmoil due to the death of the popular chief minister J. Jayalalithaa in December 2016, had aggravated their problems. They viewed the sea as an important resource for their well-being, were worried about the overexploitation of marine resources, and viewed the tsunami as a punishment by 'Mother Sea' for this overexploitation. Although aware of the likely challenges to fishing in the future, they 
were of the opinion that collective action by the villagers would help solve many problems in fishing and were optimistic about fishing as the only source of livelihood for future generations of their families.

Additionally, the FHHs mentioned the importance of the relations they maintained with formal institutions especially the state. All FHHs had ration cards and were eligible to receive free rice and other essentials through designated ration shops as part of the public distribution system. Two interviewed FHHs did not use their ration cards, as they did not have any family members who could go to the ration shops for them while they were selling fish. Although the FHHs were not happy about the quality of the food items they obtained from the ration shops, this helped them reduce some of their expenditures, especially during the fishing ban season. Among the FHHs who were eligible to receive an old age pension or a deserted wife/destitute widow allowance, only five reported obtaining such benefits. Another state benefit was the fishing ban compensation. FHHs' families that did not include an adult male did not receive fishing ban compensation. By contrast, if an adult male was present in a family, the household received compensation, regardless of whether he was involved in fishing. Indebtedness was high in the village, with loans taken from moneylenders, traders, friends, fishermen societies, self-help groups, and banks (jewellery loans). Except for the three fish auctioneers, almost all the FHHs were heavily in debt, having borrowed money from several sources. Local moneylenders and informal loan groups, therefore, dominated the relational well-being landscape of FHHs. When they needed a large amount of money, they depended on local moneylenders, despite the high interest rates. Nevertheless, FHHs were worried that they would not be able to access such loans in the future. Here, we wish to highlight that the persistence of these systems and FHHs' dependency on them is a warning sign of vulnerability and precarity. 


\section{Subjective well-being}

The FHHs explained their subjective well-being by referring to their positions in relation to their material and relational well-being. The in-depth interviews shed light on what the FHHs had and valued for their well-being. Their perceptions reflected their satisfaction, dissatisfaction, fears, and hopes, and served as relative and comparative assessments of their well-being. It is important to note that the subjective well-being of the majority of the FHHs' reflected not only their individual well-being but also the well-being of their families and the community. These social relationships provided the financial, emotional, and social support they needed, not only in their livelihoods but also in their lives.

The FHHs fish vendors identified having regular jobs as important for their emotional well-being, as this guaranteed regular income to fulfil their well-being needs. They perceived a decline in fish available and accessible to them both in the village and outside and were worried about the increasing competition from fish traders who directly purchased entire boat loads of fish. They also valued the importance of government aid to ensure their well-being. However, among those entitled to such aid, not all were in a position to access it. The oldest research participant expressed how she was ignored in government offices:

In order to have a good life, we need [an] old age pension too. I had to wait for a long time to get this pension. I got it from last year only. I do not know how many times I have gone to the office and how much money I have given them to get my work done (Widow, aged 68 years, fish vendor).

Old age pensions are extremely important for FHHs when they become physically too weak to engage in fish vending or when they do not have support from their families. The FHHs found such assistance critical for their well-being and 
highlighted the difficulties they faced in accessing it, including their illiteracy, but importantly, the caste discrimination they faced in government offices. They mentioned that when they go to government offices they have to wait in long queues, are asked for bribes and often asked to return to the office another day.

Although all the interviewed FHHs reported health problems, they neglected their own health for various reasons. They mentioned lack of time to go to government hospitals, discrimination and negligence by hospital staff, and lack of money to access private medical services as their reasons for not seeking medical treatment:

If one can have a life without health problems that will be the good life. You see, in my family, I have to spend a lot of money on medicine. I also have regular pains in my neck, knees and back. My husband and son are ill. But I am tolerating my own health problems as I cannot afford the costs (FHH and main contributor to the household economy, aged 47 years, fish vendor).

While her account shows the difficulties and problems that FHHs face in accessing health services, it also shows how they prioritize the well-being of their family members over their own. Almost all of the research participants reported headaches, lower back, hip, and knee pain.

FHHs with dependent family members valued the importance of family support. The youngest member of the FGD expressed:

Family support is important for widows like me to engage in business. My mother, who was a fish vendor, helps me with household work and taking care of my children. If she is not with me, I can't leave my two daughters alone when I go to the fish market early [in the] morning. I am happy she is there to help me (Widow, aged 29 years, fish vendor).

Apart from family support in general being key to their livelihood choices, for many FHHs, certain members of their families, especially mothers or daughters, were very 
important because they helped them with their household work and childcare, allowing them to engage in livelihoods that involved being away from home for several hours in the day. Family members also provided other forms of non-material support to the FHHs, such as love and care. Some were worried about the decline in family support due to the deteriorating health of dependent family members, their partners' alcoholism, and the marriage of their children.

\section{Concluding discussion: Well-being Pursuits in the Context of Vulnerability}

The pursuit of well-being by FHHs fish auctioneers and fish vendors reveals the varied components of the three dimensions of well-being they find important, and how they express their positions, fears and hopes related to their well-being at present and in the future. Their well-being pursuits are embedded in the contextual vulnerabilities (social marginalization, environmental insecurity and inadequate physical and financial assets) and precarities (changing market access, modernization, mechanization and increased capitalization) we have identified. The narratives of FHHs vendors and auctioneers show that well-being is multidimensional and context specific (see also McGregor and Sumner 2010; Britton and Coulthard 2013). Different well-being expectations contribute to an understanding also of the multidimensionality and constantly changing nature of vulnerability (Sumner and Mallett 2013) and precarity (Rigg 2016). The FHHs fish vendors identified regular income, savings, the destitute widow pension scheme, rations, fishing ban compensation, housing, and storage facilities related to their employment as important for their material well-being. Growing indebtedness, however, was making them more vulnerable. They hence valued the different relationships that helped them achieve their well-being expectations, emphasizing in particular the role of household and family members, neighbours, community members, formal and informal institutions (ration shops, local money lenders and loan groups). 
Their subjective well-being perspectives overlapped with their material and relational well-being, as the women emphasized issues related to their own and family members' employment, children's education, and pensions. Within this context, FHHs place different emphasis on different dimensions of well-being and how they intersect. However, a closer look at the women's narratives show that the strongest priority is directly and indirectly given to the material well-being of their families. This is clearly reflected in their perceptions of relational and subjective well-being.

The above discussion of the well-being pursuits of FHHs highlights the importance of their social location, more so in a context of precarity, intensified by increasing mechanization, deep sea fishing, and post-tsunami developments. It also confirms how they respond to increasing vulnerability in order to pursue their wellbeing objectives. Post-tsunami, many FHHs have had to move outside the village, both for purchasing and selling fish. They work long hours and travel long distances with their fish loads, especially as most of them don't have storage facilities for unsold fish or the time to prepare dried fish after they come home. Once they return home, they are burdened with household chores. These double shifts take a toll on their health. Their narratives revealed that accessing livelihoods involving mobility, was not easy for all FHHs. The post-tsunami situation brought the existing structures that worked against women to the forefront. The existing gender norms in the village hindered the mobility, especially of young widows, outside the village. The few women who challenged these norms, did so out of necessity, even though they were worried that their choice might affect the future well-being of their children. The ability to move then, contributed to a growing differentiation amongst FHHs. Well-being itself is a dynamic and changing force. We found that precarity and vulnerability co-existed and determined the wellbeing of FHHs, mediated by the social relations in which they were embedded. Those 
FHHs fish vendors who did go outside the village and did not have any older family members to help them with household chores, either depended on their children or carried the entire burden of household work themselves. FHHs with young children, were perhaps the most vulnerable, and identified family, neighbours, and the villagers as important for their well-being. Young FHHs were very careful about selecting their relationships outside the family, in particular with fish auctioneers, moneylenders and informal financial organizations, in their attempts to achieve well-being. Fish auctioneers, who are in a comparatively better position than vendors, depended on social relationships with fishers, community and fish vendors, for their ability to sustain in the market and consequent well-being.

These social relations, especially in the community, however, are also rapidly changing, as FHHs have to increasingly compete with each other for their daily sustenance in the absence of alternative livelihood and employment opportunities. They also had to compete with powerful fish buyers and adapt to other changes in trade and market relations, especially in terms of place and scale, driven by changes in fishing technologies. Since employment for FHHs was becoming both more competitive and uncertain, so were their well-being expectations, which varied over time, producing both winners and losers. Our study also confirms, as noted by Hapke and Ayyankeril (2018), that changes triggered by modernization and post-tsunami developments have impacted fishing communities differently. While women auctioneers took risks, their economic situation had generally improved after the tsunami.

As noted by Britton and Coulthard (2013) we find the social well-being approach in fisheries research could contribute to fisheries policies and governance, as it documents how different members in the household and community are affected by changes in fisheries. We have shown how FHHs who are engaged in fish vending have 
become more vulnerable due to changes in the fishing sector, including declining access to market spaces, fish landing sites, new and powerful fish buyers and depleting fish resources. We have also documented how FHHs involved in fish auctioning by expanding and strengthening their links in the market have benefitted from the same process. This shows that the ability of FHHs to respond to different vulnerabilities depend on their power or agency (Sumner and Mallett 2013). In this study we realise that those who have good social networks and a higher social status and well-being gain most due to their ability to access market and institutional supports. As shown above, within the study context, we can assume that compared to fish vendors, fish auctioneers have access to powerful fish buyers, boat owners, public facilities and are knowledgeable about changing vulnerabilities and precarities. FHHs who do not have such power become marginalized and vulnerable.

The above analysis, by highlighting both the struggles of FHHs in fish vending and fish auctioning to meet their family's and their own wellbeing expectations, and their active agency in responding to the changes they are confronting, provides some policy lessons. India's fisheries policy of 2017 acknowledges and values the important role played by women in fishing. It spells out the nature of government support to women in the areas of fisheries cooperatives, financial support, health, safety, transport, marketing and management. Most of these issues were identified as essential by the FHHs in the study and related to their various well-being aspirations. The time has come to design and implement suitable programmes to address these problems faced by FHHs, who continue to play a central role in post-harvest operations.

This research adds to the growing body of work in feminist geography which emphasizes the importance of place, time and social identity in discussions of gendered wellbeing. Even within a single village, the ability of FHHs to respond to different 
precarities and vulnerabilities is not the same, rather shaped by their social position, networks, access to financial and other resources, and importantly, mobility. More than a physical phenomenon, mobility is deeply linked here to the social norms shaping gendered activities. Without such an understanding, addressed gendered wellbeing will be a difficult task.

\section{Acknowledgements}

This work is part of the project 'Migration and collectives/networks as pathways out of poverty. Gendered vulnerabilities and capabilities of fishing communities in Asia' funded by the Research Council of Norway, headed by Professor Ragnhild Lund, Norwegian University of Science and Technology, in partnership with researchers at the Asian Institute of Technology (Thailand), the International Centre for Ethnic Studies (Sri Lanka), the University of East Anglia (UK), the Cambodian Institute for Research and Rural Development and Fisheries Management Resource Centre (FishMarc) (India). Copy-editing assistance was provided by Ms. Catriona Turner and Valerie Appleby, and FishMarc provided practical help in the field. Thanks to all the village women and men who took the time to speak with us and share their stories.

\section{References}

Assistant Director of Fisheries, Cuddalore. 2015. "Cuddalore District - Fisheries." Accessed April 24 2018. http://cuddalore.tn.nic.in/fisheries.pdf 
Bavinck, Maarten, and Johnson, Derek. 2008. "Handling the legacy of the blue revolution in India-social justice and small-scale fisheries in a negative growth scenario." American Fisheries Society Symposium 49 (1): 585-599.

Bharati, Paktavatcala. 1999. Coromandel Fishermen: Ethnography of Pattanavar SubCaste. Pondicherry: Pondicherry Institute of Linguistics and Culture.

Britton, Easkey, and Sarah Coulthard. 2013. "Assessing the social wellbeing of Northern Ireland's fishing society using a three-dimensional approach.” Marine Policy 37: 28-36. http://dx.doi.org/10.1016/j.marpol.2012.04.011

Central Marine Fisheries Research Institute and Department of Animal Husbandry Dairying and Fisheries. n.d. "Marine Fisheries Census 2010. Part II 4: Tamil Nadu." Central Marine Fisheries Research Institute (CMFRI). Accessed May 14 2018. http://eprints.cmfri.org.in/9002/1/TN_report_full.pdf

Chen, Martha. 2010. Perpetual Mourning: Widowhood in Rural India. New Delhi: Oxford University Press.

Collins, Patricia Hill and Bilge, Sirma. 2016. Intersectionality. Cambridge: Policy Press.

Crenshaw, Kimberle. 1989. "Demarginalising the Intersections of Race and Sex: A Black Feninist Critique of Antidiscrimination Doctrine, Feminist Theory and Antiracist Politics.” The University of Chicago Legal Forum 139-168.

Department of Animal Husbandry Dairying \&Fisheries. 2017. Fisheries Profile of India. Accessed December 2017. http://dahd.nic.in/sites/default/filess/India\%20Profile\%20updated_0.pdf 
Gopal, Nikita, Williams Meryl, Marilyn Porters, Kyoko Kusakabe, and Poh Sze Choo. 2014. "Gender in aquaculture and fisheries: Navigating change.” Asian Fisheries Science 27 (S): 268.

Hanson, Susan. 2010. “Gender and mobility: New approaches for informing sustainability." Gender, Place \& Culture 17 (1): 5-23. https://doi.org/10.1080/09663690903498225

Hapke, Holly M. 2001. "Petty traders, gender, and development in a South Indian fishery." Economic Geography 77 (3): 225-249. http://dx.doi.org/10.1111/j.19448287.2001.tb00163.x

Hapke, Holly M, \& Ayyankeril, Devan.2018. "Gendered livelihoods in the global fishfood economy: a comparative study of three fisherfolk communities in Kerala,

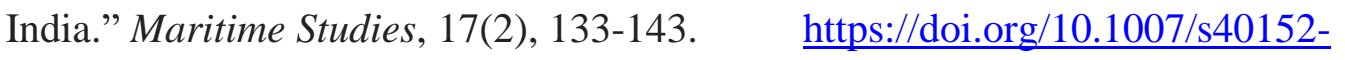
$\underline{018-0105-9}$

Hopkins, Peter. 2017. "Social Geography I: Intersectionality.” Progress in Human Geography. 43(5): 937-947. https://doi.org/10.1177\%2F0309132517743677

Jeeva, J. Charles, S. Balasubramaniam, P. Jeyanthi, and S. Ashaletha, S. 2011. "Evaluation of the post-tsunami scenario with reference to fishing technology and socio-economic conditions among the motorized craft operators in Tamil Nadu." Indian Journal of Fisheries 58 (3): 117-123. http://hdl.handle.net/123456789/695

Kuskabe, Kyoko, Ragnhild Lund, Smita Mishra Panda, Yunxian Wang, and Sengkham Vongphakdy. 2015. "Resettlement in Lao PDR: Mobility, resistance and gendered 
impacts." Gender, Place \& Culture 22 (8): 1089-1-105.

http://dx.doi.org/10.1080/0966369X.2014.939149

Lund, Ragnhild and Azmi, Fazeeha. (in press). "Female headship and exclusion from small-scale fishing in Eastern Province, Sri Lanka.” In Lund, R., Kusakabe, K., Rao, N., Weeratunge, N. (eds.) Fisherfolk in Cambodia, India and Sri Lanka: Migration, gender and well-being. Routledge, New Dheli.

McGregor, Allister, and Andy Sumner. 2010. "Beyond business as usual: What might 3-D wellbeing contribute to MDG momentum?” IDS Bulletin 41 (1): 104-12. https://doi.org/10.1111/j.1759-5436.2010.00111.x

McGregor, J. Allister, Venkatesh Salagrama, and Aditya Bahadur. 2016. "Fisheries in coastal India: Extraction, livelihoods and a way of life." In Natural Resource Extraction and Indigenous Livelihoods: Development Challenges in an Era of Globalization, edited by Emma Gilberthorpe, 76-108. London: Routledge.

Peake, Linda. 2010. “Gender, sexuality, race”. The Sage Handbook of Social Geographers, Smith, Rachel Pain, Marston, Sallie, Jones, Paul Jones, Vol. III, 5576. London: Sage.

Ram, Kalpana. 1991. Mukkuvar women: gender, hegemony and capitalist transformation in a south Indian fishing community. London: Zed Books.

Rigg, Jonathan, Katie J. Oven, Basyal, Gopi Krishnan Basyal, and Richa Lamichchane. 2016. "Between a rock and a hard place: Vulnerability and precarity in rural Nepal." Geoforum 76: 63-74. https://doi.org/10.1016/j.geoforum.2016.08.014 
Salagrama, Venkatesh. 2006. Trends in poverty and livelihood in coastal fishing communities of Orissa State, India. Rome: FAO.

Salim, Shyam S., R. Sathiadhas, R. Narayanakumar, P.K. Katiha, M. Krishnan, R.S. Biradar, Nikita Gopal, Nagesh Barik, and B. Ganesh Kuma. 2013.“Rural livelihood security: Assessment of fishers' social status in India." Agricultural Economics Research Review (Conference Number) 2013: 21-30.

Sumner, Andy, and Richard Mallett. 2013. "Capturing multidimensionality: What does a human wellbeing conceptual framework add to the analysis of vulnerability?" Social Indicators Research 113 (2): 67-690. https://doi.org/10.1007/s11205-013$\underline{0295-\mathrm{x}}$

Valentine, Gill. 2007. "Theorizing and Researching Intersectionality: A Challenge for Feminist Geography.” Professional Geographer 59: 10-21. https://doi.org/10.1111/j.1467-9272.2007.00587.x

Vivekanandan, Vriddagiri, and Hussain Mohamed Kasim. 2011. Fisheries Management Options for Tamil Nadu \& Puducherry. Technical Report. Chennai: Fisheries Management for Sustainable Livelihoods.

Waite, Louise. 2009. "A place and space for critical geography of precarity?" Geography Compass 3 (1): 412-430. https://doi.org/10.1111/j.1749$\underline{8198.2008 .00184 . \mathrm{X}}$

Weeratunge, Nireka, Christophe Béné, Rapti Siriwardane, Anthony Charles, Derek Johnson, Edward H. Allison, Prateep K. Nayak, and Marie-Caroline Badjeck. 2014. 
"Small-scale fisheries through the wellbeing lens." Fish and Fisheries 15 (2): 255279. https://doi.org/10.1111/faf.12016

White, Sarah. 2017. "Relational wellbeing: Re-centering the politics of happiness, policy and the self." Policy \& Politics 45 (2): 121-136.

https://doi.org/10.1332/030557317X14866576265970

Table 1. Demographic and social background of female heads of households 